\title{
The South Asian Free Trade Area: an Analysis of Policy Options for Sri Lanka
}

\author{
M. S. S Perera \\ University of Sri Jayewardenepura
}

\begin{abstract}
South Asia was slow to adopt regional economic cooperation. The South Asian Association for Regional Cooperation (SAARC), established in 1985, and the creation of the South Asian Free Trade Area (SAFTA) remain a widely discussed policy issue in this region. This study compares the impacts of different trade policy options on Sri Lanka using the Global Trading Analysis Project (GTAP) Model. The simulation results indicate that multilateral trade liberalisation is the best trade policy outcome for the Sri Lankan economy. The South Asian Customs Union ranks the next highest in terms of welfare for Sri Lanka, followed in order by the SAFTA and the Indo Lanka Free Trade Agreement (ILFTA). However, the proposed Sri Lanka-Bangladesh FTA did not suggest significant welfare gains to both trading partners. Furthermore, it was determined that the SAFTA can be formed without having significant trade diversion effects. Therefore, of the regional trade policy options considered in the study, Sri Lanka should focus on implementing the SAFTA. In addition, the ILFTA can continue to strengthen the SAFTA. The next stage of the SAFTA is transforming the SAFTA into the South Asian Customs Union, which is already a component of the agreement. However, this trade policy option is to be negotiated. Finally, it appears that the SAFTA still needs to find its linkages to multilateral trade liberalisation.
\end{abstract}

- JEL Classification : F1, F15

- Key Words: economic integration, regionalism, bilateralism, multilaterism

\footnotetext{
*M. S. S Perera: Senior Lecturer, Department of Business Economics, Faculty of Management Studies \& Commerce, University of Sri Jayewardenepura, Sri Lanka, Tel: +94 011 2802005, Fax: +94 011 2803653, e-mail: mperera@une.edu.au,sumudusjp2004@yahoo.co.uk.

(2009-Center for International Economics, Sejong Institution, Sejong University, All Rights Reserved.
} 


\section{Introduction}

In recent years, one important policy concern regarding trade relations among South Asian countries is whether the creation of a South Asian Free Trade Area (SAFTA) would ensure gains for its member countries or not. In December 1985, seven countries of South Asia i.e. Bangladesh, Bhutan, India, Maldives, Nepal, Pakistan and Sri Lanka formed the South Asian Association for Regional Cooperation (SAARC) to promote economic, social and cultural cooperation. In 1993, the South Asian Preferential Trade Agreement (SAPTA) was initiated by the SAARC to promote greater regional economic cooperation, which came into effect from December 1995. Subsequently, the member countries of the SAARC planned to transform SAPTA into a South Asian Free Trade Area (SAFTA), which was due to come into effect at the start of 2006. The main motivation behind the creation of SAFTA is to enhance intra-regional trade among SAARC members through the removal of tariff and non-tariff barriers and thereby enjoy the gains of regional integration and at the same time become more competitive in the global market.

According to the IMF direction of trade statistics, the intra regional trade in the South Asian region remained at 4.5 percent in 2005, which is very low compared to the other trading blocs like ASEAN which was 24.7 percent in 2005. This is a serious impediment for regional cooperation and economic integration and therefore, it is important to apply the right policy measures to enhance intra trade and foreign direct investment in the region.

Given that South Asia was slow to take up regional economic cooperation, although SAARC was established in 1985, there has been a proposal, mainly from the business community to initiate bilateral free trade agreements among SAARC member countries, particularly with India. Accordingly, Sri Lanka entered into a Free Trade Agreement (FTA) with India in 1998, which came into effect from 2000. Sri Lanka also entered into a FTA with Pakistan in 2004. Therefore, the benefits that Sri Lanka could gain as a member of the SAFTA are questionable.

Moreover, if bilateral trade agreements continue alongside the SAFTA process, countries will have to contend with a multitude of bilateral and regional agreements- what economists have referred to as a "spaghetti bowl" of overlapping trade agreements. However, the question is whether such alternative initiatives will benefit the nation as a whole, or only a few segments in the society. To reach a conclusion and be able to provide policy advice, a quantitative assessment is needed of the impacts of SAFTA, and other policy options, on the Sri Lankan 
economy. In this paper, an attempt is made to need. The objectives of the study are as follows.

i. To examine the key economic indicators of the South Asian economies, trade trends and salient features of the SAFTA.

ii. To investigate the impact of SAFTA on trade and welfare of the Sri Lankan economy.

iii. To investigate the impact of the other policy options on trade and welfare of the Sri Lankan economy.

iv. To make policy recommendations to help Sri Lanka strengthen trade relationships between SAARC countries to maximize the welfare of the country.

The study initially uses descriptive methods to investigate the key economic indicators and trade relationships between Sri Lanka and South Asian countries. In addition, the Computable General Equilibrium (CGE) model is used to estimate the impact of SAFTA and the other trade policy options on the Sri Lankan economy. The database used for the study is taken from the Global Trade Analysis Project (GTAP) as compiled by the Centre for Global Analysis, Purdue University, USA. This database is compiled for bilateral exports, imports and tariffs inclusive of other flows for 87 major countries/regions and 57 tradable commodities of the world (Dimaranan and McDougall, 2004). The database used here is pre-release 5 of version 6.0 of the GTAP database. The reference year for this database is 2001. The tariff data is mainly in the form of applied ad valorem rates. For the present analysis, we have aggregated 57 GTAP sectors into 27 sectors (Appendix Table A.2). Similarly, the 87 countries/regions are aggregated into 15 countries/regions (Appendix Table A.1).

The structure of the paper is as follows. Section 2 examines the key economic indicators and trade patterns between Sri Lanka and its South Asian trade partners. A review of some prominent features of the SAFTA is presented in Section 3. Section 4 provides the theoretical background and empirical studies to shed light into the analysis. An overview of the GTAP model is presented in section 5. The trade liberalization scenarios and simulation results are reported and discussed in Section 6. Section 7 outlines the main conclusions and policy recommendations. 


\section{Sri Lanka's Integration with the South Asian Economies}

\section{A. Sri Lanka's Economic Structure in the Context of South Asia and the World Economy}

SAARC countries differ enormously in terms of size, population and economic development. They share divergent economic, social, cultural and political arrangements. These divergences offer enormous opportunities as well as numerous difficulties and challenges in the formation of a regional bloc. One of the structural characteristics of the region is the coexistence of less developed countries with relatively more developed countries. India dominates the SAARC economic parameters including GDP and population. Some key economic indicators on South Asian countries are provided in Table 1.

In recent years, South Asia has been the second fastest growing region in the world. Yet, it remains as the region with the largest number of people living in poverty. It is home to more than half a billion poor people which is approximately 43 percent of world's poor people. The World Bank classifies the Maldives and Sri Lanka as lower middle income countries (LMC) and the other five South Asian

Table 1. Key Economic Indicators of SAARC Countries: 2003

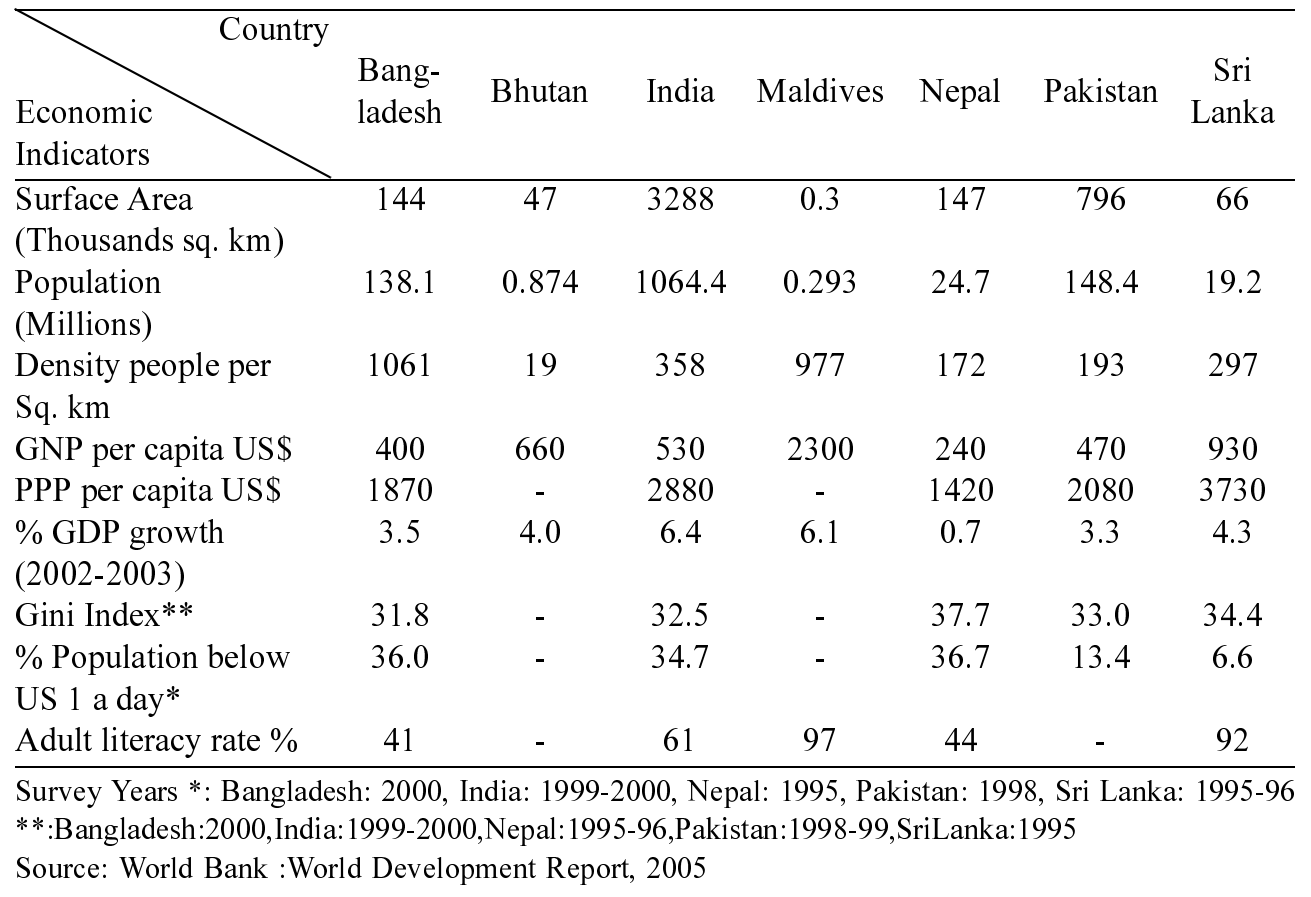


Table 2. Macroeconomic Characteristics of Different Countries/Regions: 2001

\begin{tabular}{|c|c|c|c|c|c|c|c|c|c|c|c|c|c|c|c|}
\hline Region & IND & LKA & BDG & XSA & USA & CAN & EU & ASE & HIA & JPN & $\mathrm{CHN}$ & XME & AUS_NZL & RUS_XSU & ROW \\
\hline \multicolumn{16}{|l|}{$\begin{array}{l}\text { GDP \& Trade Flow } \\
\text { (Billion US\$) }\end{array}$} \\
\hline GDP & 477.5 & 15.9 & 46.8 & 83.4 & 10082.3 & 715.1 & 7929.6 & 537.1 & 872.0 & 4177.6 & 1159.0 & 644.7 & 407.9 & 414.4 & 3715.3 \\
\hline Imports & 75.9 & 7.1 & 12.1 & 17.4 & 1321.0 & 246.1 & 2592.3 & 394.0 & 411.5 & 430.1 & 313.8 & 219.3 & 92.1 & 131.7 & 1111.4 \\
\hline \multicolumn{16}{|l|}{ Relative Size in the World (\%) } \\
\hline Exports & 0.9 & 0.1 & 0.1 & 0.2 & 12.9 & 3.9 & 36.5 & 6.4 & 6.0 & 6.6 & 5.5 & 3.0 & 1.3 & 2.1 & 14.6 \\
\hline Imports & 1.0 & 0.1 & 0.2 & 0.2 & 17.9 & 3.3 & 35.1 & 5.3 & 5.6 & 5.8 & 4.3 & 3.0 & 1.2 & 1.8 & 15.1 \\
\hline \multicolumn{16}{|l|}{$\begin{array}{l}\text { Trade Dependence Ratio } \\
\text { (\%) }\end{array}$} \\
\hline Export/GDP & 12.7 & 40.7 & 17.0 & 16.6 & 8.8 & 37.4 & 31.7 & 81.6 & 47.1 & 10.8 & 32.7 & 32.6 & 22.3 & 35.1 & 27.2 \\
\hline \multicolumn{16}{|c|}{ Factor Share in Value Added } \\
\hline Land & 0.102 & 0.115 & 0.064 & 0.111 & 0.005 & 0.007 & 0.006 & 0.042 & 0.014 & 0.003 & 0.047 & 0.008 & 0.010 & 0.032 & 0.018 \\
\hline Unskilled Labour & 0.345 & 0.402 & 0.372 & 0.373 & 0.318 & 0.336 & 0.249 & 0.284 & 0.311 & 0.358 & 0.445 & 0.247 & 0.322 & 0.358 & 0.312 \\
\hline Skilled Labour & 0.108 & 0.108 & 0.108 & 0.108 & 0.224 & 0.163 & 0.171 & 0.105 & 0.180 & 0.218 & 0.107 & 0.113 & 0.220 & 0.116 & 0.143 \\
\hline Capital & 0.435 & 0.364 & 0.438 & 0.394 & 0.450 & 0.478 & 0.570 & 0.546 & 0.491 & 0.420 & 0.383 & 0.568 & 0.431 & 0.430 & 0.509 \\
\hline Natural Resources & 0.010 & 0.010 & 0.019 & 0.013 & 0.003 & 0.015 & 0.003 & 0.023 & 0.003 & 0.002 & 0.018 & 0.063 & 0.017 & 0.063 & 0.017 \\
\hline $\begin{array}{l}\text { Factor Proportions } \\
\text { (\%)Unskilled/Total Labour }\end{array}$ & 76.2 & 78.8 & 77.6 & 77.5 & 58.6 & 67.3 & 59.3 & 72.9 & 63.3 & 62.1 & 80.6 & 68.6 & 59.4 & 75.5 & 68.5 \\
\hline
\end{tabular}


countries as low-income countries (LIC). Table 2 presents data on GDP, external trade, trade dependence, factor endowments, and the relative size of the economies of Sri Lanka and other regions included in the GTAP model (Appendix Table A.2). It can be seen that the data are remarkably asymmetrical among regions with respect to their size of GDP, exports and imports.

The macroeconomic data indicates that the South Asian region accounts for only 2 percent of world GDP, 1.3 percent of exports and 1.5 percent of imports. Judging by these figures, any change in trade policy in South Asia is likely to have negligible impact on the world economy. In comparison with the other countries in South Asia, it is apparent that the relative size of India is significantly higher than the other South Asian economies. India accounts for about 75 percent of GDP, 69 percent of exports and 67 percent of imports in the South Asian region while Sri Lanka only contributes around 5 percent of GDP, exports and imports in the region. Therefore, Sri Lanka is a minor player in South Asia. However, it can be noted that Sri Lanka has the highest trade dependence ratio in the region. From this, it is evident that Sri Lanka has an open economy. It also suggests a significant variation in factor endowments between the South Asian economies and other economies in the world, reflecting that there is ample scope for Heckscher-Ohlin type trade to occur (Siriwardena, 2004). The South Asian region has relatively higher shares of unskilled labour in the labour force in comparison with the other economies.

\section{B. Sri Lanka's Trade with and South Asian Countries and Rest of the World}

Table 3 reports the share of each region's exports and imports by sector in total world trade. The 27 industries have been aggregated into 7 categories for the purpose of analysis. The agricultural sector represents paddy rice, processed rice, wheat, cereal grains, vegetables, fruits and nuts. All other food products are included under processed foods. The other manufacturing sector includes, leather and wood products, chemical, rubber and plastic products, metal products and other primary products. Electronic equipment, machinery and equipment necessaries, petroleum and coal products are included under capital intensive manufacturing.

From the figures in the Table 3 it can be seen that the South Asian countries represent relatively small shares in world trade which is consistent with their small GDP levels. It appears that textiles and wearing apparel are the leading exports from the region and accounts for 8.09 percent of exports to the world market. Although, in Sri Lanka's case is wearing apparel exports are less than 1 percent of 
Table 3. Exports and Import Shares in World Trade by Sector in 2001

(Percentage)

\begin{tabular}{|c|c|c|c|c|c|c|c|c|c|c|c|c|c|c|c|}
\hline Region & IND & LKA & $\overline{B D G}$ & $\overline{\mathrm{XSA}}$ & USA & CAN & EU & $\overline{\mathrm{ASE}}$ & HIA & JPN & CHN & XME & AUS_NZL & RUS_XSU & $\mathrm{ROW}$ \\
\hline \multicolumn{16}{|l|}{ Shares in World } \\
\hline \multicolumn{16}{|l|}{ Exports (\%) } \\
\hline Agricultural Products & 2.28 & 0.56 & 0.08 & 0.67 & 16.65 & 4.23 & 24.61 & 9.15 & 0.51 & 0.72 & 3.44 & 1.92 & 3.51 & 2.26 & 29.40 \\
\hline $\begin{array}{l}\text { Textile and Wearing } \\
\text { Apparel }\end{array}$ & 3.54 & 0.85 & 1.62 & 2.08 & 5.06 & 1.23 & 25.53 & 6.91 & 11.44 & 2.75 & 16.08 & 1.49 & 0.26 & 0.88 & 20.29 \\
\hline Other Manufacturing & 0.83 & 0.04 & 0.04 & 0.07 & 10.69 & 5.04 & 42.76 & 4.73 & 4.41 & 4.85 & 6.07 & 1.52 & 1.50 & 3.26 & 14.19 \\
\hline Services & 1.00 & 0.09 & 0.07 & 0.24 & 17.65 & 2.74 & 40.93 & 4.99 & 8.53 & 3.19 & 1.80 & 2.04 & 1.41 & 1.14 & 14.19 \\
\hline Natural Resources & 0.50 & 0.02 & 0.03 & 0.05 & 4.15 & 4.72 & 15.24 & 5.11 & 0.71 & 1.58 & 2.90 & 22.28 & 3.44 & 10.10 & 29.17 \\
\hline Total Exports (\%) & 0.88 & 0.09 & 0.11 & 0.20 & 12.89 & 3.87 & 36.46 & 6.35 & 5.96 & 6.57 & 5.50 & 3.05 & 1.32 & 2.11 & 14.64 \\
\hline $\begin{array}{l}\text { Textile and Wearing } \\
\text { Apparel }\end{array}$ & 0.34 & 0.36 & 0.64 & 0.18 & 21.98 & 2.18 & 31.18 & 3.04 & 4.72 & 6.68 & 5.95 & 3.05 & 1.16 & 1.75 & 16.80 \\
\hline Other Manufacturing & 1.12 & 0.09 & 0.15 & 0.26 & 15.79 & 3.50 & 37.26 & 4.43 & 5.29 & 4.37 & 4.79 & 2.81 & 1.30 & 1.83 & 17.02 \\
\hline $\begin{array}{l}\text { Capital Intensive Manu- } \\
\text { facturing }\end{array}$ & 0.75 & 0.07 & 0.11 & 0.20 & 21.42 & 4.07 & 32.12 & 6.67 & 5.63 & 4.43 & 4.50 & 2.88 & 1.36 & 1.14 & 14.65 \\
\hline Services & 0.95 & 0.07 & 0.06 & 0.21 & 14.11 & 2.65 & 42.22 & 4.85 & 4.92 & 6.80 & 3.15 & 3.32 & 1.30 & 2.30 & 13.08 \\
\hline Natural Resources & 2.98 & 0.09 & 0.15 & 0.24 & 18.89 & 2.02 & 30.88 & 4.44 & 8.21 & 10.75 & 3.54 & 1.57 & 0.88 & 2.89 & 12.48 \\
\hline Total Imports (\%) & 1.03 & 0.10 & 0.16 & 0.24 & 17.91 & 3.34 & 35.15 & 5.34 & 5.58 & 5.83 & 4.25 & 2.97 & 1.25 & 1.79 & 15.07 \\
\hline
\end{tabular}


Table 4. Sri Lanka's Trade with South Asia

(US\$ millions)

\begin{tabular}{lcccccccccccc}
\hline \multirow{3}{*}{ Country } & \multicolumn{4}{c}{ Sri Lanka's Exports to } & \multicolumn{7}{c}{ Sri Lanka's Imports from } \\
\cline { 2 - 13 } & 1990 & $\%$ & 1995 & $\%$ & 2003 & $\%$ & 1990 & $\%$ & 1995 & $\%$ & 2003 & $\%$ \\
\hline Bang- & 10.0 & 14.5 & 12.0 & 11.9 & 10.41 & 3.0 & 9.0 & 4.9 & 6.0 & 1.1 & 5.63 & 0.50 \\
ladesh & & & & & & & & & & \\
India & 20.0 & 29.0 & 32.0 & 31.7 & 241.14 & 70.2 & 118.0 & 64.1 & 469.0 & 86.1 & 1076.17 & 91.6 \\
Maldives & 7.0 & 10.1 & 14.0 & 13.9 & 54.39 & 15.8 & 6.0 & 3.3 & 17.0 & 3.1 & 22.65 & 1.9 \\
Nepal & 0.0 & 0.0 & 0.0 & 0.0 & 1.66 & 0.5 & 0.0 & 0.0 & 1.0 & 0.2 & 0.01 & 0.00 \\
Pakistan & 32.0 & 46.4 & 43.0 & 42.5 & 36.13 & 10.5 & 51.0 & 27.7 & 52.0 & 9.5 & 70.98 & 6.0 \\
Total & & & & & & & & & & & & \\
(South & 69.0 & 100 & 101.0 & 100 & 343.73 & 100 & 184 & 100 & 545.0 & 100 & 1175.44 & 100 \\
Asia) & & & & & & & & & & & & \\
World & 1983.0 & 3798.0 & 4931.5 & & 2685.0 & 5185.0 & & 6523.15 & \\
As \% & 3.5 & & 2.7 & & 6.9 & & 10.6 & & 10.5 & & 18.01 & \\
\hline
\end{tabular}

Source: Department of Commerce, Ministry of Trade: Sri Lanka

the world share. Agricultural products from South Asia comprise 3.59 percent of world exports and 4.55 percent of world imports. South Asia accounts for 1.28 percent of world exports, of which India's share is 0.88 percent. This is 68.75 percent of South Asia's share of world exports; highlighting India's dominant position in the region. South Asia's share of world imports is 1.53 percent of which India's share is 67.3 percent.

\section{Bilateral Trade between Sri Lanka and South Asian Countries}

Table 4 illustrates Sri Lanka's trade with South Asian countries. According to the figures in Table 4, it India appears to be the major trading partner of Sri Lanka in South Asia, with Pakistan the second most important trading partner in the region.

While trade between Sri Lanka and Bangladesh has declined over recent years, exports to the Maldives have shown healthy growth. With regional cooperation making only modest progress, bilateral free trade agreements are gaining momentum in the region. Consequently, Sri Lanka has entered into bilateral free trade agreements with India and also with Pakistan. There is also a proposal to enter into a bilateral FTA with Bangladesh.

\section{Some Salient Features of SAFTA}

The process of economic integration in South Asia gathered momentum with the 
implementation of the SAPTA in 1995 under the broad framework of the SAARC. SAPTA has, however, come to be viewed as an interim platform in the move towards economic integration in South Asia. In 1996, South Asian governments committed themselves to the creation of a South Asian Free Trade Area (SAFTA) by the year 2001, but not later than 2006. One reason given for accelerating the timetable for regional free trade was that it would be a way of preparing for more global competition which would result from the new round of trade negotiations under the aegis of the World Trade Organization (WTO). In order to prepare, it was decided that the SAARC Council for Economic Co-operation (CEC) and the InterGovernmental Expert Group (IGEG) should meet and discuss at length an action plan and terms of reference for SAFTA. The parameters set out for SAFTA in these discussions included tariff eliminations without any import restrictions, removal of "structural impediments" to regional trade, harmonizing of customs

Table 5. Tariff Reductions Proposed under SAFTA

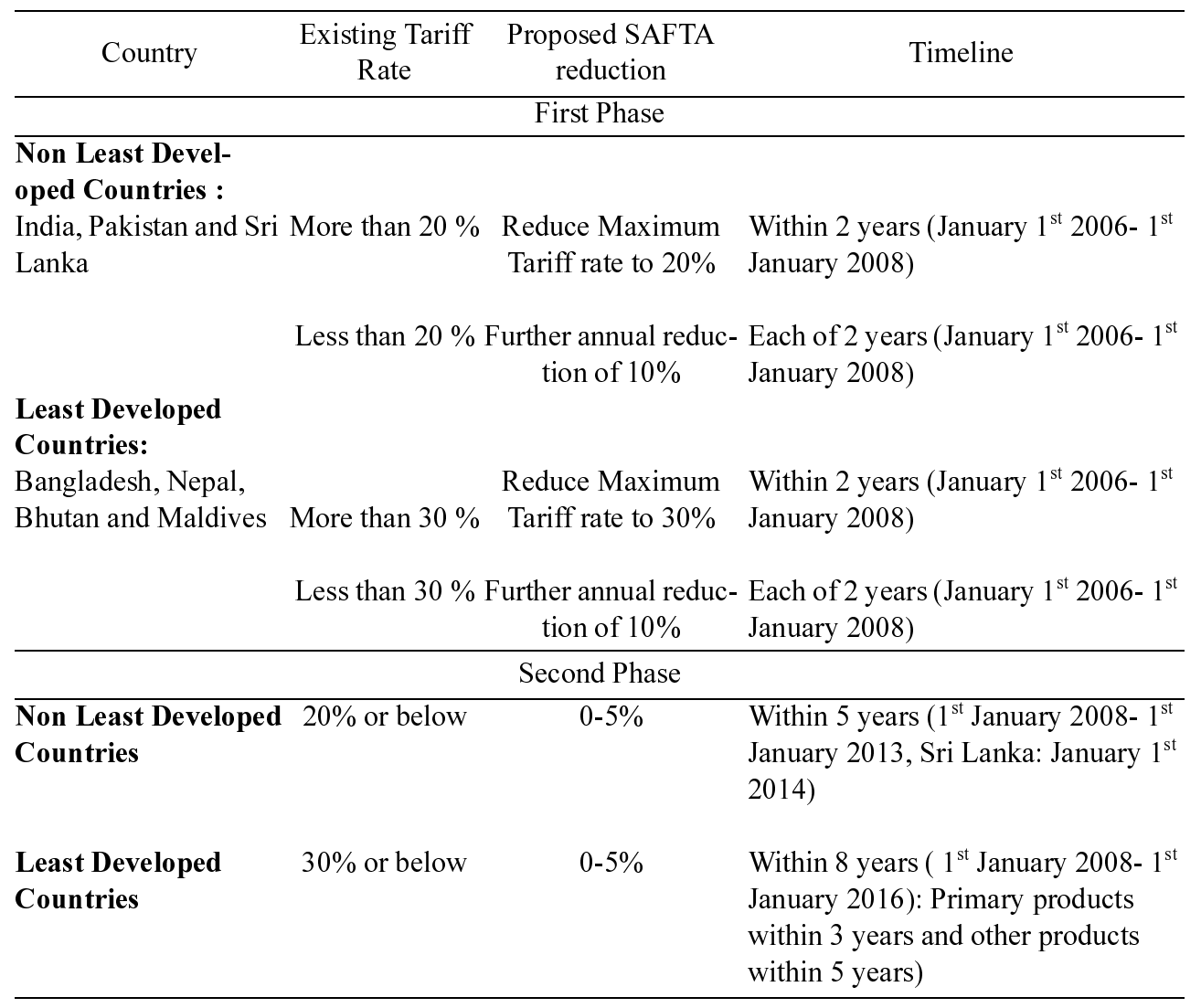

Source: The World Bank, Trade Policies in South Asia: An Overview -2004 
procedures and documentations, bank facilitation, port and transport facilitation, establishment of a reviewing and monitoring mechanism, facilitation of traderelated services and ensuring "equitable" benefits to all member countries.

For the same reasons that SAPTA made very slow progress, for many years it was difficult to obtain unequivocal commitment to SAFTA. But finally, on $6^{\text {th }}$ of January 2004, at the twelfth SAARC Summit held in Islamabad, the seven member countries of the SAARC signed a framework free trade agreement and the SAARC Secretariat formally announced the enforcement of SAFTA from 1st January 2006. The Committee of Experts proposed the tariff reduction schedule in two phases, which is illustrated in the table 5 .

The agreement is to be completed by 2016 and all contracting parties will need to reduce their tariffs from $0-5$ percent at the full implementation of SAFTA. In addition, the report envisaged that it would become a Customs Union by 2015 and an Economic Union by 2020.

Even though SAFTA is an ambitious agreement to achieve its fundamental goal of trade liberalization, it is being criticized because its coverage has been limited to trade in goods. In other words the agreement does not include service trade, investment and non-border market access issues (Siriwardana, 2008). SAFTA also failed to negotiate complex rules of origin requirements which are also important in maintaining an effective agreement (Sally, 2006; Das, 2007).

\section{Literature Review}

\section{A. Theoretical Background on the Economic Integration}

One notable trend in the global economy in recent years has been the accelerated movement toward regional economic integration. "Regionalism", "regional trading agreement," and "free trade areas" are defined as a group of countries which are formed with the objective of reducing barriers to trade between member countries. Contrary to whatever the name suggests, these groupings or unions may be concluded between countries not necessarily belonging to the same geographical region (Bhagwati, 1993).

As pointed out by Bhagwati (1993), it encourages countries to enter into preferential trade arrangements with geographically proximate countries rather than with distant ones, because the former would more likely be trade creating, lead to a larger improvement in welfare (of the home country), and thus be "natural", while 
the latter would more likely be trade diverting.

Like regionalism, "multilateralism" is a general term that has several meanings. Multilateralism also refers to the lowering of trade barriers on a nondiscriminatory, Most -Favored-Nation (MFN) basis, in which any tariff concessions granted to a partner are also extended to the rest of the world. In the multilateral system, progress towards free trade is slow because every country has a veto and fashioning trade-offs takes time (Bhagwati, 1993). In a regionalized world, progress could be quicker, both within and between blocs. But irreconcilable differences could crop up under either approach and even worse, if countries focus more on regional or bilateral deals, they may start to feel that working through the WTO is simply not worth the candle. A free multilateral system might end up being replaced by one of several free-trade blocks, which may or may not trade more or less freely with each other.

\section{B. Review of Empirical Research}

The impact of both SAPTA and SAFTA has received attention in different studies. Only a few studies, however, have attempted to quantify the possible economic impacts on the member countries. Such impact assessment is necessary to decide upon an arrangement, which at least will not be harmful for any of the members. The existing studies reflect the lack of consensus about the economic outcomes of preferential trade arrangements in the SAARC region on its member countries.

Siriwardana (2001) undertook a quantitative assessment of likely implications of bilateral trade liberalisation between Sri Lanka and the SAARC countries. Simulations were performed using the Global Trade Analysis Project (GTAP) model to quantify the impact of liberalised trade. The results indicated that Sri Lanka may experience some welfare gains from bilateral trade liberalization with Asian trading partners.

Bandara and Yu (2001) used the GTAP model to examine whether SAFTA is a desirable Preferential Trade Arrangement (PTA) or not. The result suggests that under a unilateral liberalization scenario, India would gain substantially, while NAFTA and the EU, the biggest trading partners of South Asian countries, would also gain. Sri Lanka and Bangladesh would gain considerably while rest of South Asia would lose. Under the SAFTA scenario, India would be the only significant welfare gainer, while small countries gain marginally. Bangladesh is even expected to lose. 
The study undertaken by Dushini, Weerakoon and Janaka Wijayasirsi (2001) used descriptive analysis to investigate South Asian regional integration on the Sri Lankan economy. The study mentioned that, in the case of Sri Lanka, SAPTA has had no discernible impact on Sri Lanka's trade in South Asia. In addition, the study analysed the impact of the Indo-Lanka FTA and it was revealed that FTA has more benefits and confers freer access for Sri Lankan exports to the Indian market. Further, it mentioned that bilateral trade arrangements can undermine broad support for the formation of SAFTA.

Srinivasan (1994) and Srinivasan and Canonero (1995) used the gravity model to estimate the impact of regional integration in South Asia. They concluded that multilateral trade liberalisation on a global basis would yield higher return for the region compared to preferential trade arrangements within the region. Their studies also suggest that small economies in the region would gain much more from preferential trade liberalisation than larger economies.

After SAPTA turned to SAFTA, a number of studies examined the potential impacts of the latter. Pigato et.al (1997) found SAFTA to be "highly desirable" and proposed that this would result in significant welfare gains, especially for small counties. However, Tennakoon (2001) concluded that SAFTA would generate significant benefits for Sri Lanka and India, but would have adverse welfare effects for the other SAARC members.

Samaratunge (1999) also used the gravity model to explore the impacts of SAARC-Asia-Pacific Economic Cooperation (APEC) trade relations. The study indicated that the prospects for export expansion of SAARC region into APEC countries are narrow within the 1991-1995 policy frameworks. However, the same method used by Rajapakse and Arunatilake (1997) to study the implications of SAFTA for Sri Lanka indicated that Sri Lanka would gain from SAFTA.

Arvind Panagariya (2002) used Partial Equilibrium Analysis to investigate whether preferential trade liberalisation in South Asia made sense. The conclusions were that forming a South Asian FTA would probably prove harmful overall, with a low-tariff country such as Sri Lanka benefiting and high tariff country such as India losing. Therefore, on economic grounds, a persuasive case for the FTA could not be made.

Siriwardana (2003) used the GTAP model to investigate the effects of two plausible trade policy scenarios for free trade in South Asia, i.e. whether to establish an FTA or a customs union. The findings indicated that whatever form it takes, trade liberalisation is beneficial to South Asian countries in terms of both 
GDP and welfare. The extent of the benefits varies among the members with Sri Lanka appearing to reap the most in both scenarios. However, the gains for all countries in the region markedly increased under a customs union, although India stands to gain the least in relative terms.

Siriwardana (2004) undertook a study to investigate the impact of an Indo Sri Lanka Free Trade Agreement on the Sri Lankan economy and its implications for free trade in South Asia using the GTAP model. The findings were that both Sri Lanka and India would experience some welfare gains from ILFTA. The extension of such a trade agreement to all SAARC nations may create significant welfare improvements in Sri Lanka.

Siriwardana (2007) used the GTAP model to examine the effects of a proposed free trade agreement between India and Bangladesh. The study found that a FTA could provide ample opportunities for Bangladesh to expand its trade with India and to slowdown the growing trade imbalance.

In reviewing previous empirical research, it can be seen that general equilibrium modelling is comparatively rare in the SAARC region, particularly on the Sri Lankan economy. Furthermore, none of the studies focus on a comparative study of the impact of SAFTA and other policy options on trade and welfare in relation to the Sri Lankan economy. This paper tries to fill this gap in a modest way.

\section{Analytical Framework: GTAP Model}

\section{A. Overview of the GTAP Model}

The analytical framework used to quantify the impact of bilateral tariff reductions is the well-known GTAP model (Hertel, 1997). It is a comparativestatic, multi regional CGE model of the Johansen type comprising a system of linear equations in percentage change of variables. The modelling of each region in GTAP is based on the ORANI model (Dixon et al., 1982). The GTAP model has a number of notable features which include product differentiation by country of origin, explicit recognition of savings by regional economies, a capital goods producing sector in each region service investment, international mobility of capital, multiple trading regions, multiple goods and primary factors, empiricallybased differences in production technology and consumer preferences across regions, and explicit recognition of a world transport sector. It also accommodates several policy variables, including taxes and subsidies on commodities and primary 
factors.

In each region both factor and commodity markets are assumed to be perfectly competitive. Producers operate under constant returns to scale, where the technology is described by the Leontief and CES (Constant Elasticity of Substitution) functions. Two broad categories of inputs into production are identified; intermediate inputs and primary factors. Each regional sector is designated as choosing a mixture of inputs to minimize total cost for a given level of output. At the first level, producers use composite units of intermediate inputs and primary factors in fixed proportions according to a Leontief function. At the second level of production, intermediate input composites are obtained as combinations of imported bundles and domestic goods of the same input-output class, and primary factor input composites are created as combinations of skilled labor, unskilled labor, capital, land, and natural resources. A CES function is used in forming both types of composites. Finally, at the third level, imported bundles are created via a CES aggregation of imported goods of the same class from each region.

On the demand side, the GTAP model adopts a sophisticated specification of consumer behavior that allows for differences in both price and income responsiveness of demand in different regions, depending on the level of development and regional specific demand patterns. Each region has a single representative household that receives all the income generated through payments to primary factors and net tax revenue. The representative household is governed by an aggregate utility function over private household consumption, government consumption and savings. The aggregate utility is modelled using a Cobb-Douglas function over composite commodities where the demand for the later is a CES aggregation of imports and domestic goods. Private household consumption is explained by a CDE (Constant Difference of Elasticities) expenditure function. (Siriwardana, 2003). Capital accumulation occurs in each region according to a technology that is similar to producing current goods, except that it requires only domestic and imported intermediate inputs. This capital creation services the investment that is financed by a global pool of savings. Each region contributes a share of its income to a savings pool at a global bank that is designed to mediate world savings and investment. The structure of the model is illustrated in the diagram below.

A competitive equilibrium in this global economy is such that, given the prices of commodities and factors, demand for goods and supply of goods are equal at the 
Figure 1. Overview of the Model

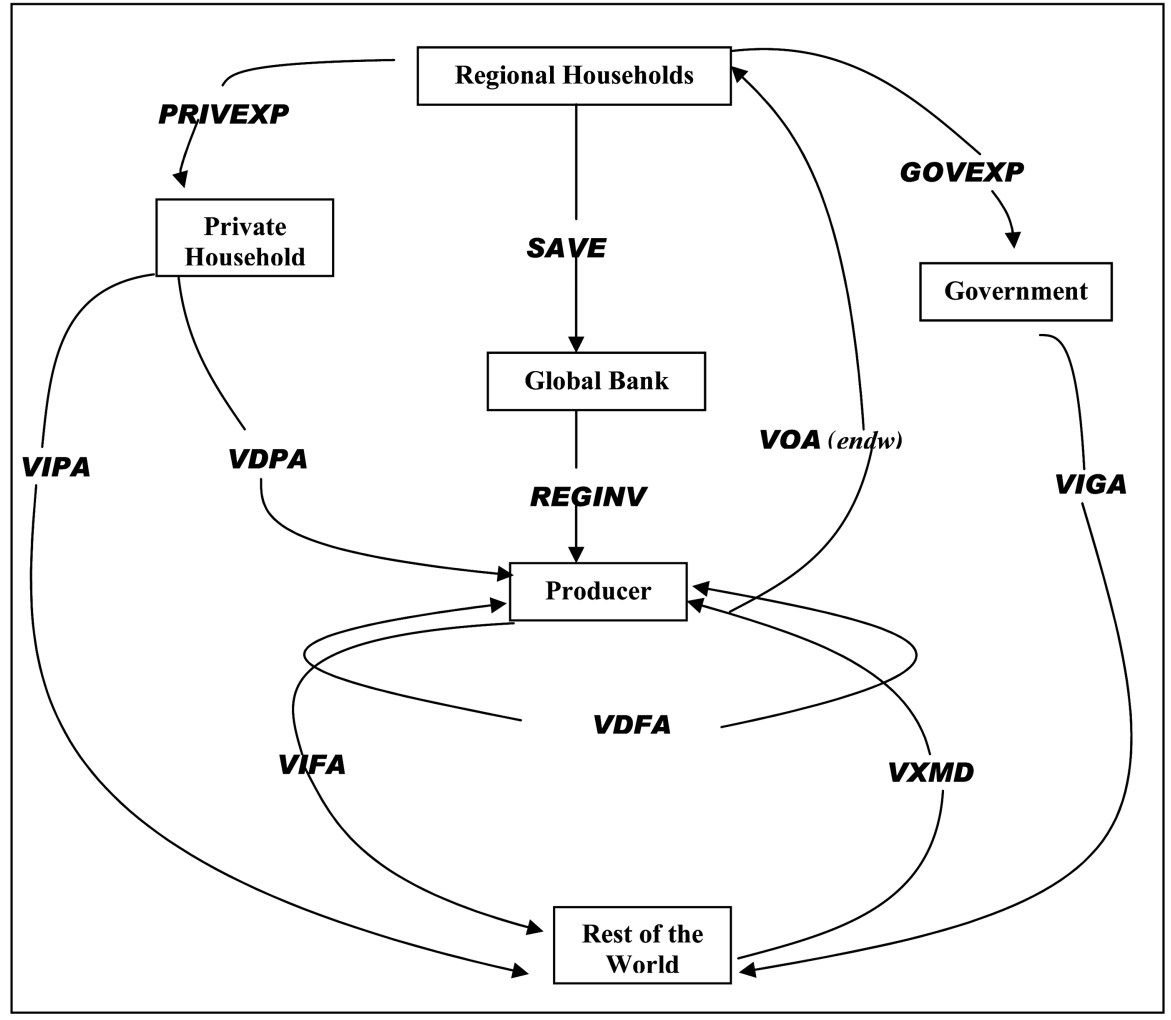

Source: Hertel: 1997

Where:

PRIVEXP $=$ Private household Expenditure

GOVEXP $=$ Government Expenditure

SAVE $=$ Value of net Savings

$\mathrm{VOA}=$ Value of Output at Agent's Prices of endowment commodities

REGINV $=$ Gross Investment in Region

VIPA= Import Payments from households

$\mathrm{VDPA}=$ Value of Domestic purchases by private house holds

VIGA $=$ Value of Domestic purchases by Government

VIFA= Import payment from firms

VDFA=Value of domestic purchases by firms

$\mathrm{VXMD}=$ Value of exports at market price

regional as well as at the global level; factor market clears for each region and at the world level; consumers of each region maximize their utility subject to their income constraints; and the government budget and trade are balanced for each region. 


\section{B. Measurement of Variables and Source of Data}

This study uses the data in the input/output tables in GTAP version 6 database, which represents data for the 2001 world economy. The global trade model presented above requires data on output, imports, exports, consumption and government demand, employment of labour and capital, intermediate inputs, and base year prices for each sector and region included in the model. It also needs tax and tariff rates ${ }^{1}$ for each product.

The welfare change under the simulation of regional integration is given by equivalent variation. This is be accomplished by implementing a decomposition of the equivalent variation (EV) welfare measure currently employed in the GTAP model. The regional household equivalent variation, resulting from a policy shock, is equal to the difference between the expenditure required to obtain the new level of utility at initial prices and the initial expenditure to obtain the new level of utility at initial prices and the initial expenditure. The decomposition of equivalent variation and their definitions have been presented as follows:

- Changes in allocative efficiency

Allocative efficiency refers to the efficient sector-wise allocation of scarce resources to produce the optimal combination of output. In an open economy context it also refers to efficiency in resource use in purchasing imported products.

- Changes in country's terms of trade (TOT)

The Terms of trade are defined as the ratio of the price received for tradables (export price index) to the price paid for tradables (import price index). McDougall (1998) explains that in a model like GTAP, which differentiates product by country of origin, changes in terms of trade can arise from changes in relative prices of different source specific varieties of the same commodity.

- Changes in prices of investment goods and savings (I-S effect)

The I-S effect indicates how much investment takes place in each economy during the period of tariff reductions to make sure that the sum of regional investment matches changes in global savings.

\section{Limitations of the GTAP Model}

The standard GTAP model is a static model which cannot capture the dynamic effects from trade liberalization such as the benefits of increased competition,

These tariff rates reflect the applied rates in the year 2001. It should be noted that these are not the actual tariff rates at actual line level. Rather they are highly aggregated rates using trade data as weights. 
potential economies of scale, and the incentives for investment brought about by a preferential trading agreement, technology and productivity change which will be fully realized only in the long run. Furthermore, in conducting the simulations the tariff data in the GTAP data base has been used. Iit would have been more appropriate to include the Uruguay Round commitments by Sri Lanka and South Asian trade partners in conducting a meaningful FTA simulation. The product items considered under the SAFTA and other trade policy options are very narrowly defined at 6-digit HS code level and it is difficult to aggregate them in a sensible way according to the GTAP commodity classification. The results will be interpreted on the industries classified in the GTAP model. Despite the above mentioned limitations, GTAP is a useful tool for generating comparative static results for a variety of trade reform scenarios, the comparison of which can provide direction in the path toward further trade reform.

\section{Trade Policy Scenarios and the Simulation Results}

\section{A. Trade Policy Scenarios}

In this study, five simulations are performed, one is for the SAFTA and rest contains different bilateral FTAs between Sri Lanka and the other SAARC member countries and other policy options.

- Simulation 1: Preferential Trade Liberalisation in South Asia - SAFTA

Considers full implementation of the SAFTA in its originally proposed form where all SAARC countries reduce their existing tariff rates to 5\%. If the existing tariff rates are less than $5 \%$ it will remain unchanged.

\section{- Simulation 2: South Asian Custom Union}

Since, the SAFTA aim is to transform into a customs union in the future, this simulation considers SAFTA plus a $15 \%$ uniform external tariff rate to other regions and to the rest of the world. ${ }^{2}$

\section{- Simulation 3: Indo-Lanka Free Trade Agreement (ILFTA)}

Under the ILFTA both India and Sri Lanka have negative lists to safeguard their domestic industries. The tariff concessions are not applied to the products on these negative lists. Therefore, an attempt is made to incorporate the impact of having a "negative list" on the welfare of the Sri Lankan economy. To make a comparison

${ }^{2}$ This was chosen arbitrarily as it is not $15 \%$ for all the commodities, 
between a free trade situation and a partial free trade situation this simulation is performed under two scenarios as follows:

a) Indo-Lanka Full Free Trade Liberalisation Scenario

In this situation tariffs are reduced to zero on all products traded between two countries.

\section{b) Indo- Lanka FTA(with negative list)}

Under this situation no tariff reductions are made on the product categories included in the negative lists of Sri Lanka and India and tariffs are reduced to zero on the duty free items and on other items in the positive list. Tariff reductions have been designed on a reciprocal basis in accordance with the Indo Lanka FTA. The tariff reduction under this simulation is depicted in Appendix Table A.3.

- Simulation 4: Proposed Sri Lanka-Bangladesh Free Trade Agreement

Under this simulation, a Sri Lanka-Bangladesh full-free-trade liberalisation situation is considered.

\section{- Simulation 5 : Multilateral Trade Liberalisation}

This considers the situation where all countries cut tariff rates by $100 \%$ to examine the welfare impact if there was global free trade.

In performing all the simulations non-tariff barriers are assumed to be absent. In addition it is assumed that aggregate employment of labour and land are fixed in each country/region.

\section{B. Simulation Results}

For the purposes of policy analysis, six simulations are performed, as outlined in the previous section. The welfare impacts are ascertained and decomposed into different effects. The best policy outcome is determined on the basis of equivalent variation (EV) that arises under each of the policy outcomes. The GTAP model simulation results reported are the estimated impacts of trade liberalisation on important macroeconomic variables, trade relationships and economic welfare. The simulation results are presented with the objective of evaluating the best policy outcome of the South Asian trade liberalisation with particular focus on the Sri Lankan economy.

(1) Impact of Trade Liberalization on Macroeconomic Variables

The macroeconomic effects of trade liberalisation in South Asia are given in the Appendix Table A.4. Several important points emerge from these projections. The following figures illustrate the projected changes on a number of important macroeconomic variables under different trade policy options for the Sri Lankan 
Figure 2. Impacts on GDP in Sri Lanka under Different Trade Policy Options

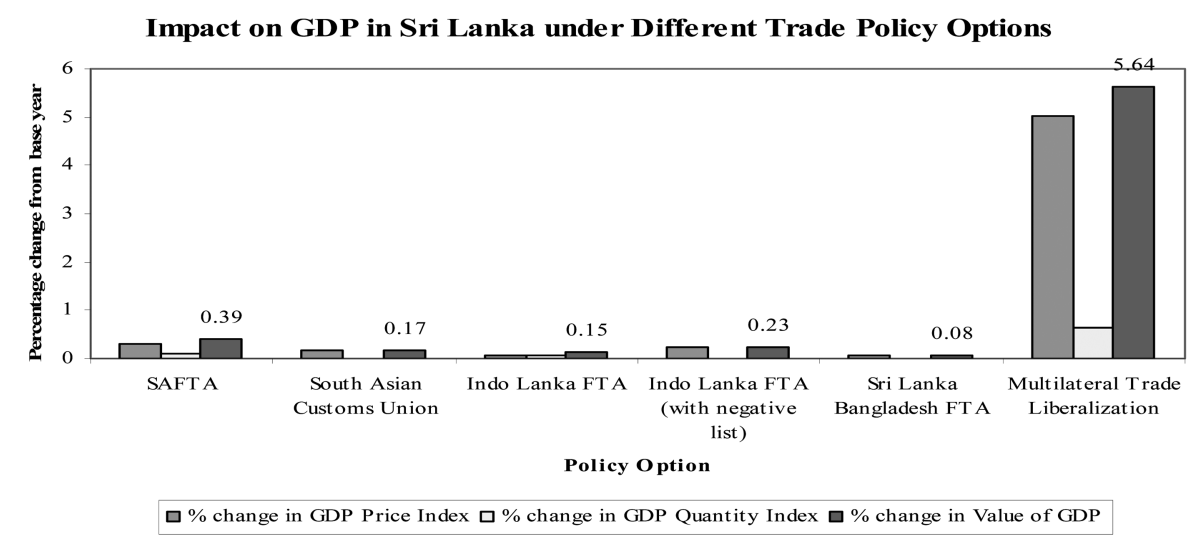

Source: Simulation results derived from GTAP version 6 (Database 2001)

economy.

The results indicate that multilateral trade liberalisation brings the highest improvement to GDP in Sri Lanka. The second best option is the SAFTA followed by the South Asian Customs Union. At the bilateral level it can be concluded that Sri Lanka's GDP will increase considerably more under the Indo Lanka FTA than under the proposed Sri Lanka-Bangladesh FTA.

From Figure 3 it is evident that house hold utility is highest under multilateral trade liberalization, followed by a South Asian Customs Union, SAFTA and the bilateral trade agreements.

From the estimated results, it is clear that returns to factors of production are

Figure 3. Change in Household Utility in Sri Lanka under Different Trade Policy Options

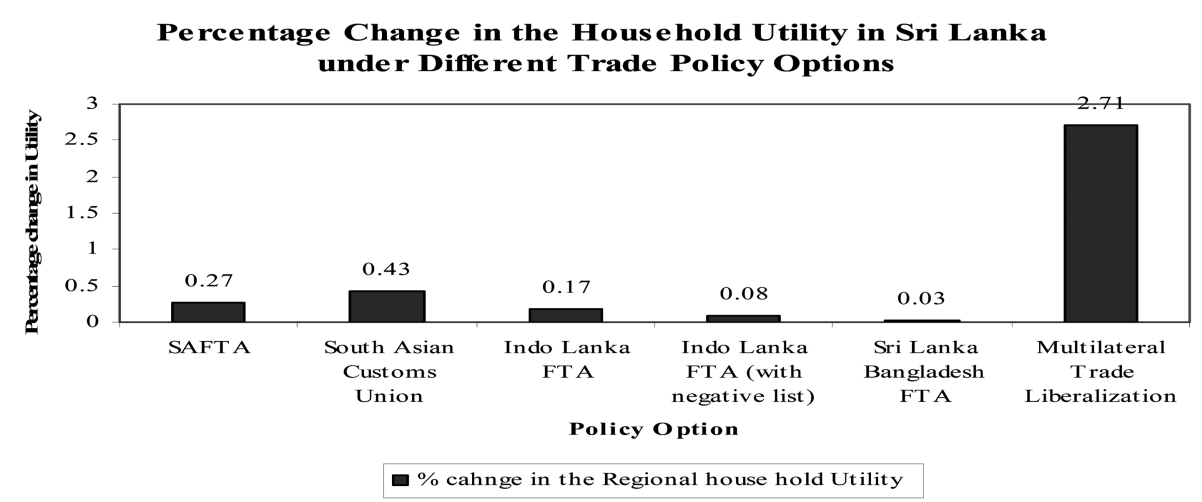

Source: Simulation results derived from GTAP version 6 (Database 2001) 
Figure 4. Changes in Returns to Factors of Production in Sri Lanka under Different Trade Policy Options

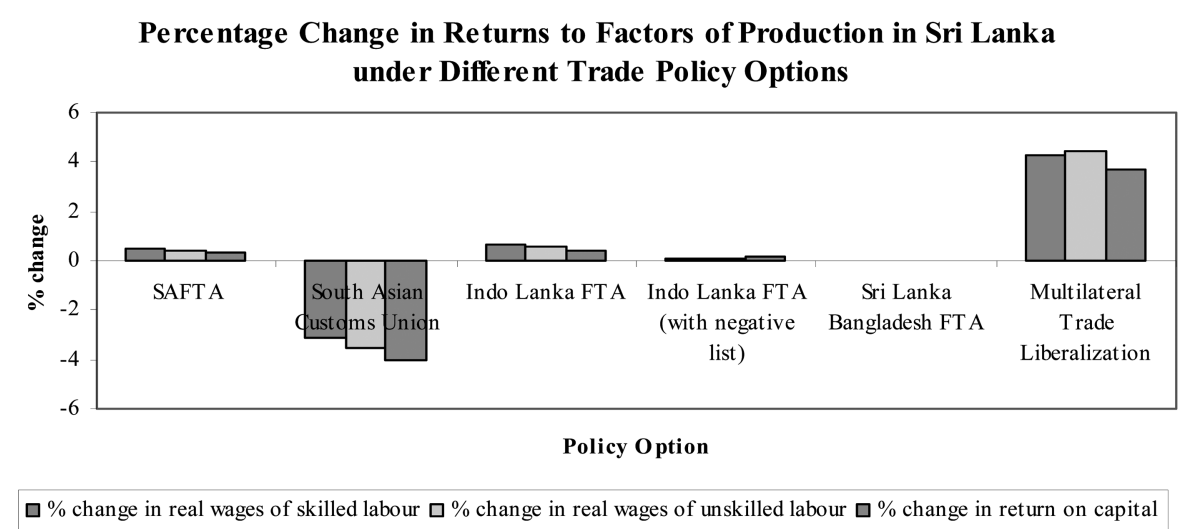

Source: Simulation results derived from GTAP version 6 (Database 2001)

highest under the multilateral trade liberalisation. Figure 4 shows that under the SAFTA and Indo Lanka FTA real returns to factors of production will improve in Sri Lanka.

\section{(2) Impact of Trade Liberalization on Welfare}

Table 6 illustrates the estimated equivalent variation under different trade policy options. The EV is an absolute monetary measure of welfare improvement in terms of income that results from the fall in import prices when tariffs are reduced or eliminated. Therefore, in deciding the best policy option, it is important to examine the magnitude of EV under different trade policy options.

The estimated results reveal that welfare is much higher under multilateral trade liberalisation than under the other policy scenarios. The South Asian Customs Union is the next best policy outcome for the Sri Lankan economy. Furthermore, it is evident that projected welfare under the SAFTA is considerably higher than under the Indo Lanka FTA. Moreover, the estimated welfare is positive for other members of the RTA under the SAFTA. Therefore, it can be concluded that Sri Lanka needs to initiate steps to implement the SAFTA with the support of other regional trading partners.

\section{(3) Impact of Trade Liberalisation on Sectoral Exports and Imports}

Table 7 demonstrates the projected results of the impact of different trade policy options on total exports and imports in industries in Sri Lanka. ${ }^{3}$

$\overline{{ }^{3} \text { The respective percentage }}$ changes are listed in Appendix Table A.5. 
Table 6. Simulation Results: Decomposition of Equivalent Variation

(US\$ Million)

\begin{tabular}{|c|c|c|c|c|c|c|c|c|c|c|c|c|}
\hline \multirow{3}{*}{ Region } & \multicolumn{12}{|c|}{ Policy Scenarios } \\
\hline & \multicolumn{4}{|c|}{ SAFTA } & \multicolumn{4}{|c|}{ South Asian Customs Union } & \multicolumn{4}{|c|}{ Indo-Lanka Full FTA } \\
\hline & $\begin{array}{l}\text { Allocative } \\
\text { Efficiency }\end{array}$ & $\begin{array}{c}\text { TOT } \\
\text { Effect }\end{array}$ & $\begin{array}{c}\text { I-S } \\
\text { Effect }\end{array}$ & Total & $\begin{array}{l}\text { Allocative } \\
\text { Efficiency }\end{array}$ & $\begin{array}{l}\text { TOT } \\
\text { Effect }\end{array}$ & $\begin{array}{c}\text { I-S } \\
\text { Effect }\end{array}$ & Total & $\begin{array}{l}\text { Allocative } \\
\text { Efficiency }\end{array}$ & $\begin{array}{c}\text { TOT } \\
\text { Effect }\end{array}$ & I-S Effect & Total \\
\hline$\overline{I n d i a ~(I N D) ~}$ & 173.36 & 103.58 & -1.64 & 275.30 & 4035.27 & -646.26 & 14.73 & 3403.74 & 21.47 & 27.99 & -0.37 & 49.08 \\
\hline Sri Lanka (LKA) & 14.88 & 22.89 & 0.26 & 38.04 & 1.49 & 56.56 & 2.81 & 60.85 & 12.18 & 11.33 & -0.01 & 23.49 \\
\hline Bangladesh (BDG) & 59.28 & -32.94 & -3.90 & 22.43 & 493.83 & -77.43 & 11.65 & 428.06 & -0.06 & -0.32 & 0.02 & -0.36 \\
\hline \multirow{2}{*}{$\begin{array}{l}\text { Rest of South Asia } \\
\text { (XSA) }\end{array}$} & \multicolumn{4}{|c|}{$\begin{array}{c}\text { Indo-Lanka FTA } \\
\text { ( with negative list) }\end{array}$} & Proposed Sri & i Lanka-H & Banglad & esh FTA & \multicolumn{4}{|c|}{ Multilateral Trade Liberalization } \\
\hline & $\begin{array}{l}\text { Allocative } \\
\text { Efficiency }\end{array}$ & $\begin{array}{c}\text { TOT } \\
\text { Effect }\end{array}$ & $\begin{array}{c}\text { I-S } \\
\text { Effect }\end{array}$ & Total & $\begin{array}{l}\text { Allocative } \\
\text { Efficiency }\end{array}$ & $\begin{array}{c}\text { TOT } \\
\text { Effect }\end{array}$ & $\begin{array}{c}\text { I-S } \\
\text { Effect }\end{array}$ & Total & $\begin{array}{l}\text { Allocative } \\
\text { Efficiency }\end{array}$ & TOT Effe & ectI-S Effect & Total \\
\hline $\begin{array}{l}\text { Rest of South Asia } \\
\text { (XSA) }\end{array}$ & -0.14 & -0.31 & -0.01 & -0.46 & -0.01 & -0.06 & 0.00 & -0.07 & 895.26 & -156.72 & -12.40 & 726.14 \\
\hline
\end{tabular}

Source: Simulation results derived under different policy scenarios from GTAP version 6 (Database 2001) 
Table 7. Export and Import Directions of Sri Lankan Industries

\begin{tabular}{|c|c|c|}
\hline Policy Option & Increase in Exports & Increase in Imports \\
\hline SAFTA & $\begin{array}{l}\text { - Oil seeds and vegetable oil } \\
\text { - Metal Products } \\
\text { - Paper products and publishing } \\
\text { - Other primary products } \\
\text { - Chemical rubber and plastic products } \\
\text { - Beverage and tobacco } \\
\text { - Capital intensive manufacturing } \\
\text { - Milk products } \\
\text { - Meat products } \\
\text { - Other food products }\end{array}$ & $\begin{array}{l}\text { - Sugar } \\
\text { - Rice } \\
\text { - Plant based fibers and crops } \\
\text { - Fish products } \\
\text { - Food products necessaries }\end{array}$ \\
\hline $\begin{array}{l}\text { South Asian Cus- } \\
\text { toms Union }\end{array}$ & $\begin{array}{l}\text { - Plant based fibers and crops } \\
\text { - Meat products } \\
\text { - Food products necessaries } \\
\text { - Other food products } \\
\text { - Leather and wood products } \\
\text { - Paper products and publishing } \\
\text { - Metal products } \\
\text { - Milk products } \\
\text { - Other manufacturing } \\
\text { - Other primary products } \\
\text { - Services } \\
\text { - Natural resources }\end{array}$ & $\begin{array}{l}\text { - Sugar } \\
\text { - Rice } \\
\text { - Oil seeds and vegetable oil } \\
\text { - Beverage and tobacco }\end{array}$ \\
\hline $\begin{array}{l}\text { Indo Lanka FTA } \\
\text { (full trade liberal- } \\
\text { ization scenario) }\end{array}$ & $\begin{array}{l}\text { - Metal products } \\
\text { - Paper products and publishing } \\
\text { - Electronic equipment } \\
\text { - Chemical, rubber and plastic products } \\
\text { - Machinery and equipment necessaries } \\
\text { - Other primary products }\end{array}$ & $\begin{array}{l}\text { - Rice } \\
\text { - Wheat and cereal grain } \\
\text { - Food products necessaries } \\
\text { - Vegetable, fruits and nuts } \\
\text { - Fish products }\end{array}$ \\
\hline $\begin{array}{l}\text { Indo Lanka FTA } \\
\text { (with negative } \\
\text { list) }\end{array}$ & $\begin{array}{l}\text { - Metal products } \\
\text { - Paper products and publishing } \\
\text { - Electronic equipment } \\
\text { - Machinery and equipment necessaries } \\
\text { - Other primary products }\end{array}$ & $\begin{array}{l}\text { - Machinery and Equipment nec- } \\
\text { essaries } \\
\text { - Electronic equipment }\end{array}$ \\
\hline $\begin{array}{l}\text { Sri Lanka Bang- } \\
\text { ladesh FTA }\end{array}$ & $\begin{array}{l}\text { - Oil seeds and vegetable oil } \\
\text { - Metal products } \\
\text { - Capital intensive manufacturing } \\
\text { - Other food products }\end{array}$ & - Natural Resources (oil, gas) \\
\hline
\end{tabular}


Table 7. Export and Import Directions of Sri Lankan Industries (continued)

\begin{tabular}{lll}
\hline Policy Option & \multicolumn{1}{c}{ Increase in Exports } & \multicolumn{1}{c}{ Increase in Imports } \\
\hline Multilateral & - Wearing apparel & - Wheat and cereal grain \\
Trade Liberaliza- & - Leather and wood products & - Vegetable, fruits and nuts \\
tion & - Paper products and publishing & - Oil seeds and vegetable oil \\
& - Electronic equipment & - Rice \\
& - Other primary products & - Sugar \\
& - Metal products & - Milk products \\
- Beverage and tobacco & - Fish products \\
& - Other primary products & - Meat products \\
& - Natural resources & - Food products necessaries \\
& & - Chemical, rubber and plastic products \\
& & - Other manufacturing \\
& & - Petroleum and coal products \\
& & - Capital intensive manufacturing \\
&
\end{tabular}

Source: Simulation results derived from GTAP version 6 (Database 2001)

From the estimated results it can be concluded that under all trade policy options the manufacturing sector will benefit more than the agricultural sector. It can be seen that in most of the manufacturing sectors exports will increase more than imports under the trade liberalisation scenarios. The findings reveal that the metal product industry will immensely benefit under all trade policy options and therefore, Sri Lanka's metal products should have good opportunities in the world market. However, rice and sugar appear to be imported products under all trade policy options.

\section{(4) Impact on Intra Regional Trade}

The simulation results presented in Table 8 indicate that the intra regional trade share in the South Asian region will change under different trade policy options.

From the results it is clear that under the SAFTA, South Asian countries will

Table 8. Projected Intra Regional Trade under different Trade Policy Options

\begin{tabular}{lc}
\hline \multicolumn{1}{c}{ Policy Option } & Projected Intra Trade Level (\%) \\
\hline SAFTA & 6.2 \\
South Asian Customs Union & 5.8 \\
Indo Lanka Full Trade Liberalization Scenario & 4.5 \\
Indo Lanka FTA (with negative list) & 4.3 \\
Proposed Sri Lanka Bangladesh FTA & 4.2 \\
Multilateral Trade Liberalization & 4.6 \\
\hline
\end{tabular}

Source: Estimated from the simulation results derived from GTAP version 6 (Database 2001) 
trade more with the regional trading partners, or in other words the trade creation effect is highest in the case of the SAFTA. It is apparent that the Indo Lanka FTA will also enhance intra trade share in the region. The proposed Sri LankaBangladesh FTA does not seem to make much of a contribution in boosting intra regional trade in the region. The results also imply that South Asian countries tend to trade less with regional trading partners when moving to deeper integration stages.

\section{Conclusion and Policy Recommendations}

Several important conclusions can be drawn from the analysis of different trade liberalisation scenarios in South Asia and its impact on the Sri Lankan economy. Trade policies affect consumers and producers differently and it is important to take an overall view in judging their effectiveness. Therefore, the impacts on important macroeconomic variables, welfare and trade were all taken into consideration in determining appropriate policy options for Sri Lanka. According to estimated equivalent variation measures, welfare under multilateral trade liberalization is much higher than under the other policy scenarios. The South Asian Customs Union ensures the second highest welfare measure, SAFTA is next, followed by the bilateral trade agreements.

Judging by all of these impacts on welfare variables it can be concluded that multilateral trade liberalisation is the best policy option for the Sri Lankan economy. This is consistent with the WTO arguments that multilateral trade liberalisation remains the best path to freer trade and development. However, since it takes long time to achieve this, it is argued that trading partners and neighbours will try to advance liberalisation through regional and bilateral trade agreements. From the findings it was revealed that the South Asian Customs Union is the next best policy outcome for the Sri Lankan economy. It is also evident that projected welfare under the SAFTA is considerably higher than under the Indo Lanka FTA. In addition the analysis found that welfare is estimated to be positive for other members of the RTA under the SAFTA. Therefore, it can be concluded that Sri Lanka needs to initiate steps to implement the SAFTA with the support of other regional trading partners. Furthermore, it can be concluded that the present Indo Lanka FTA ensures positive welfare gains to both the Sri Lankan economy and to the Indian economy without seriously harming the other members of the region. The proposed Sri Lanka-Bangladesh FTA was estimated to be of little benefit to 
both Sri Lanka and Bangladesh.

\section{Proposed Trade Policy Options for Sri Lanka}

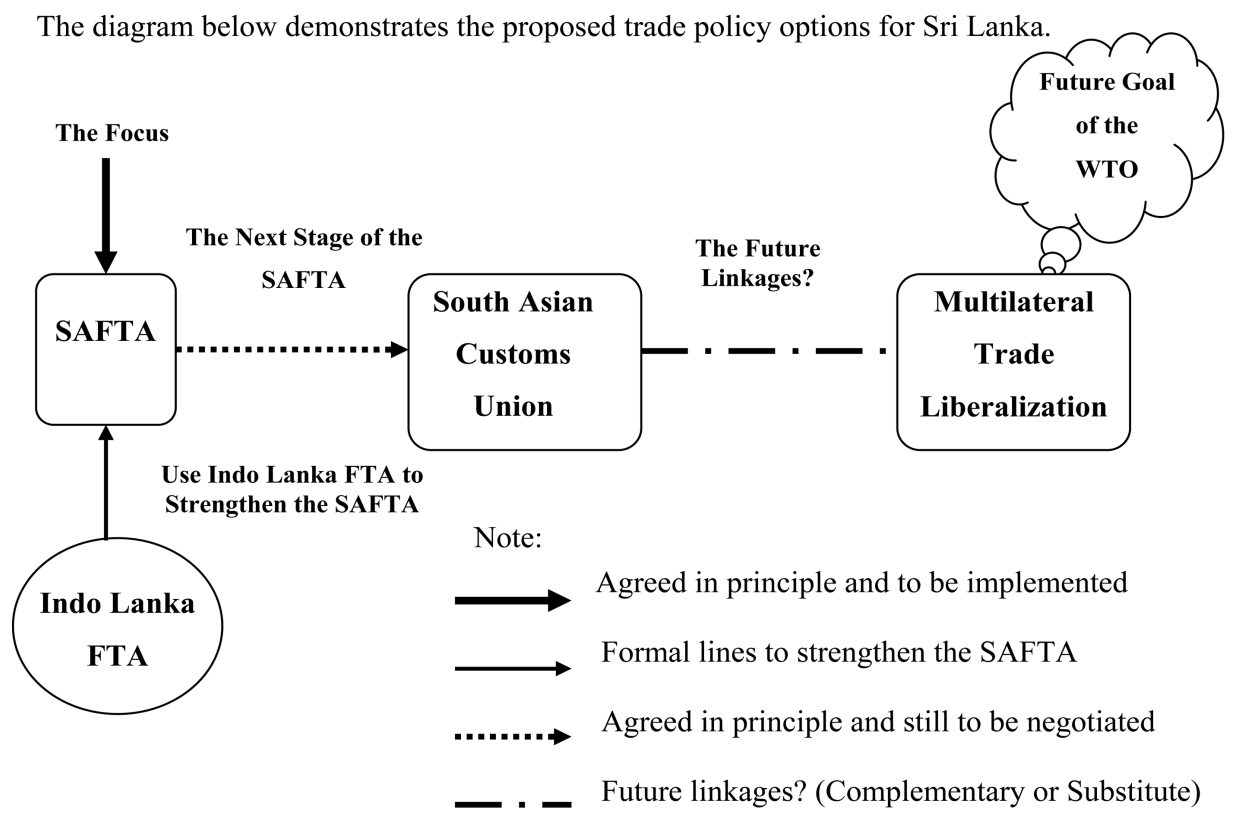

It seems apparent that for Sri Lanka, regionalism should be served as the first best trade policy option under multilateral trading system. Also, among the different trade policy options under the regionalistic approach, Sri Lanka might rather focus on implementing the SAFTA as it ensures the highest welfare to Sri Lanka of the trade policy options considered. It appears that in Sri Lanka's case, the SAFTA is complementary and regionalism can help to sustain multilateralism. In other words RTAs should be rather "building blocks" towards freer global trade than being stumbling blocks (Bhagwati and Panagariya: 1993). In that sense the findings of this study are consistent with the theoretical framework of economic integration.

The most powerful economic arguments against regional and bilateral trade agreements are that they can cause trade diversion and trade distortions and ultimately undermine the multilateral system because of their discriminatory nature. However, the results of this study reveal that the SAFTA can be formed without causing significant trade diversion effects, or without bringing serious harm to outside members of the RTA.

From Sri Lanka's point of view it is important to cooperate with regional trading partners, as being a small economy Sri Lanka cannot compete in the world market 
as an individual economy. Hence, Sri Lanka needs to join with regional trading partners and implement the SAFTA to expand its world market opportunities.

The findings of this study also indicate that the manufacturing sector will benefit more than the agricultural sector under all trade policy options. Most of the manufacturing sector's exports will increase more under the trade liberalisation scenarios than will imports. It is also revealed that the metal product industry will benefit immensely under all trade policy options considered and therefore, good opportunities exist for Sri Lanka's metal products in the world market. The findings suggest that Sri Lanka is a net importer of many of agricultural products under the SAFTA. In fact, rice and sugar appear to be imported products under all trade policy options. Therefore, in implementing the SAFTA it is important that the government develop appropriate policies that link with the industrial sector in Sri Lanka, particularly the private sector which plays a significant role in the economy. Hence, in successfully implementing the SAFTA the government should build a proper network with the industrial sector, including the private sector, research institutions and universities in Sri Lanka.. For instance, the government can make use of research undertaken by the universities to develop the country's industrial sector. Encouraging research and development is an important function to facilitate innovative products, and proper training is vital to human resource development in the country.

As illustrated in the previous diagram Sri Lanka should focus on implementing the SAFTA. In addition, the Indo Lanka FTA can play a role in strengthening the SAFTA. The next stage of the SAFTA is transforming the SAFTA into the South Asian Customs Union, which is already included in the agreement. However, this trade policy option still has to be negotiated. Finally, it can be seen that the SAFTA still needs to find linkages (complementary or substitute) to multilateral trade liberalisation.

\section{Acknowledgements}

The author acknowledges the helpful comments and suggestions received from the Associate Professor Suthiphand Chirathivat attached to the Faculty of Economics, Chulalongkorn University, Thailand.

Received 16 August 2008, Revised 21 January 2009, Accepted 4 February 2009 


\section{Appendices}

Table A.1. Regional Aggregation of the GTAP Database

\begin{tabular}{|c|c|c|c|}
\hline No & Code & Aggregated Region & Member Regions \\
\hline 1 & IND & India & India \\
\hline 2 & LKA & Sri Lanka & Sri Lanka \\
\hline 3 & BGD & Bangladesh & Bangladesh \\
\hline 4 & XSA & Rest of South Asia & Bhutan, Maldives, Nepal and Pakistan \\
\hline 5 & USA & United States of America & United States of America \\
\hline 6 & CAN & Canada & Canada \\
\hline 7 & EU & European Union & $\begin{array}{l}\text { Austria, Belgium, Denmark, Finland, France, Ger- } \\
\text { many, United Kingdom, Greece, Ireland, Italy, Lux- } \\
\text { embourg, Netherlands, Portugal, Spain, and Sweden }\end{array}$ \\
\hline 8 & ASE & ASEAN-6 & $\begin{array}{l}\text { Indonesia, Malaysia, Philippines, Singapore, Thai- } \\
\text { land and Vietnam }\end{array}$ \\
\hline 9 & HIA & High Income Asia & Hong Kong, Korea and Taiwan \\
\hline 10 & JPN & Japan & Japan \\
\hline 11 & $\mathrm{CHN}$ & China & China \\
\hline 12 & XME & Rest of Middle East & $\begin{array}{l}\text { Bahrain, Iran, Iraq, Israel, Jordan, Kuwait, Lebanon, } \\
\text { Oman, Qatar, Saudi Arabia, Syrian Arab Republic, } \\
\text { United Arab Emirates and Yemen }\end{array}$ \\
\hline \multicolumn{2}{|c|}{13 AUS_NZL } & Australia \& New Zealand & Australia and New Zealand \\
\hline 14 & RUS_XSU & $\begin{array}{l}\text { Russian Ferderation and } \\
\text { Rest of Soviet Union }\end{array}$ & $\begin{array}{l}\text { Russian Ferderation and Rest of Former Soviet } \\
\text { Union }\end{array}$ \\
\hline 15 & ROW & Rest of the World & $\begin{array}{l}\text { Mexico, Central America and the Caribbean, Colom- } \\
\text { bia, Peru, Venezuela, Rest of Andean Pact, Argen- } \\
\text { tina, Brazil, Chile, Uruguay, Rest of South America, } \\
\text { Rest of North America, Rest of EFTA, Switzerland, } \\
\text { Rest of FTAA, Hungary, Poland, Rest of Central } \\
\text { European Associates, Turkey, Morocco, Rest of } \\
\text { North Africa, Botswana, Rest of South African Cus- } \\
\text { toms Union, Rest of South African Customs Union, } \\
\text { Mozambique, Tanzania, Zambia, Zimbabwe, Other } \\
\text { Southern Africa, Uganda, Rest of Sub-Saharan } \\
\text { Africa, Rest of Oceania, Rest of East Asia, Rest of } \\
\text { Europe, Albania, Bulgaria, Croatia, Cyprus, Czech } \\
\text { Republic, Hungary, Malta, Poland, Romania, Slova- } \\
\text { kia, Slovenia, Estonia, Latvia, Lithuania, Turkey, } \\
\text { Tunisia, Rest of SACU, Malawi, Mozambique, Tan- } \\
\text { zania, Zambia, Zimbabwe, Rest of SADC, Madagas- } \\
\text { car }\end{array}$ \\
\hline
\end{tabular}


Table A.2. Commodity Aggregation of the GTAP Database

\begin{tabular}{|c|c|c|c|}
\hline No. & Code & Aggregated Sector & Commodity/Service Category \\
\hline$\overline{1}$ & PDR_PCR & Rice; Paddy and Processed & Paddy rice, Processed rice \\
\hline 2 & WHT_GRO & Wheat, Cereal Grains & Wheat, Cereal Grains nec \\
\hline 3 & V_F & Vegetables and fruits & Vegetables, fruit, nuts \\
\hline 4 & OSD_VOL & Oil seeds and vegetable oil & Oil seeds, Vegetable oils and fats \\
\hline 5 & PFB_OCR & Plant based fibers and crops & Plant-based fibers, Crops nec \\
\hline 6 & C_B & Sugar & Sugar cane, sugar beet \\
\hline 7 & RMK_MIL & Dairy Products and milk & Dairy products, Raw milk \\
\hline 8 & FSH & Fishing & Fishing \\
\hline 9 & CMT_OMT & Meat & Bovine meat, Meat products nec, \\
\hline 10 & OFD & Food Products nec & Food Products nec \\
\hline 11 & B_T & $\begin{array}{l}\text { Beverages and tobacco prod- } \\
\text { ucts }\end{array}$ & Beverages and tobacco products \\
\hline 12 & OFP & All other food products & $\begin{array}{l}\text { Animal products nec, Cattle, Sheep } \\
\text { Goats, Horse, Processed foods. }\end{array}$ \\
\hline 13 & TEX & Textiles & Textiles \\
\hline 14 & WAP & Wearing apparel & Wearing apparel \\
\hline 15 & LEA_LUM & Leather, wood products & Leather products, Wood products \\
\hline 16 & PPP & Paper Products & Paper Products and Publishing \\
\hline 17 & CRP & $\begin{array}{l}\text { Chemical, rubber, plastic } \\
\text { products }\end{array}$ & Chemical, rubber, plastic products \\
\hline 18 & I_S_NFM_FMP & Metal Products & $\begin{array}{l}\text { Basic metal products, Metals nec., Fer- } \\
\text { rous metals }\end{array}$ \\
\hline 19 & ELE & Electronic Equipment & Electronic Equipment \\
\hline 20 & OME & $\begin{array}{l}\text { Machinery and Equipment } \\
\text { nec. }\end{array}$ & Machinery and Equipment nec. \\
\hline 21 & $\mathrm{O} \_\mathrm{M}$ & Other Manufacturing & Manufactures nec. \\
\hline 22 & $\mathrm{P} \_\mathrm{C}$ & Petroleum \& Coal & Petroleum \& Coal Products \\
\hline 23 & CIM & $\begin{array}{l}\text { Capital Intensive Manufac- } \\
\text { turing }\end{array}$ & $\begin{array}{l}\text { Motor vehicles and parts, Transport } \\
\text { equipment nec, Electronic equipment, }\end{array}$ \\
\hline 24 & T_S & Tradeable Services & $\begin{array}{l}\text { Construction, Trade, Transport nec, Sea } \\
\text { Transport, Air transport, Communica- } \\
\text { tion, Financial services nec, Insurance, } \\
\text { Business services nec, Recreational and } \\
\text { other services }\end{array}$ \\
\hline 25 & NTS & Non Tradeable Services & $\begin{array}{l}\text { Public Administration, Defense, Educa- } \\
\text { tion, Health, Dwellings, Water, Electric- } \\
\text { ity }\end{array}$ \\
\hline 26 & OthPrimary & Other Primary products & Wool, Silk worm, cocoon \\
\hline 27 & NRE & $\begin{array}{l}\text { Natural Resources and } \\
\text { Extracts }\end{array}$ & $\begin{array}{l}\text { Forestry, Minerals nec ,Oil and Gas, } \\
\text { Coal }\end{array}$ \\
\hline
\end{tabular}


Table A.3. Level of Bilateral Tariff Cuts under Indo Lanka FTA(with negative list)

\begin{tabular}{|c|c|c|c|}
\hline & Industry/Commodity & $\begin{array}{l}\text { Tariff Cut on Imports } \\
\text { from Sri Lanka }\end{array}$ & $\begin{array}{l}\text { Tariff Cut on Imports } \\
\text { from India }\end{array}$ \\
\hline 1 & Paddy Rice \& Processed Rice & No tariff cut & No tariff cut \\
\hline 2 & Wheat, Cereal Grains & No tariff cut & $100 \%$ tariff cut \\
\hline 3 & Vegetables, Fruits \& Nuts & No tariff cut & $100 \%$ tariff cut \\
\hline 4 & Oil Seeds, Vegetable oil & No tariff cut & $100 \%$ tariff cut \\
\hline 5 & Plant based fibers \& Crops Nec. & No tariff cut & $100 \%$ tariff cut \\
\hline 6 & Sugar & No tariff cut & $100 \%$ tariff cut \\
\hline 7 & Milk Products & No tariff cut & $100 \%$ tariff cut \\
\hline 8 & Fish Products & No tariff cut & $100 \%$ tariff cut \\
\hline 9 & Meat products & No tariff cut & $100 \%$ tariff cut \\
\hline 10 & Food Products Nec. & No tariff cut & $100 \%$ tariff cut \\
\hline 11 & Beverage \& Tobacco & No tariff cut & No tariff cut \\
\hline 12 & Other Food Products & No tariff cut & $100 \%$ tariff cut \\
\hline 13 & Textiles & $35 \%$ tariff cut & $25 \%$ tariff cut \\
\hline 14 & Wearing Apparel & $35 \%$ tariff cut & $50 \%$ tariff cut \\
\hline 15 & Leather \& Wood Products & $35 \%$ tariff cut & $50 \%$ tariff cut \\
\hline 16 & Paper Products \& Publishing & $35 \%$ tariff cut & $50 \%$ tariff cut \\
\hline 17 & Chemical, Rubber and Plastic Products & No tariff cut & No tariff cut \\
\hline 18 & Metal Products & $35 \%$ tariff cut & $50 \%$ tariff cut \\
\hline 19 & Electronic Equipment & $100 \%$ tariff cut & $100 \%$ tariff cut \\
\hline 20 & Machinery \& Equipment Nec & $100 \%$ tariff cut & $100 \%$ tariff cut \\
\hline 21 & Other Manufacturing & $35 \%$ tariff cut & $100 \%$ tariff cut \\
\hline 22 & Petroleum and Coal Products & No tariff cut & $100 \%$ tariff cut \\
\hline 23 & Capital Intensive Manufacturing & No tariff cut & $100 \%$ tariff cut \\
\hline 24 & Tradeable Services & No tariff cut & No tariff cut \\
\hline 25 & Non Tradeable Services & No tariff cut & No tariff cut \\
\hline 26 & Other Primary Products & $35 \%$ tariff cut & No tariff cut \\
\hline 27 & Natural Resources & No tariff cut & No tariff cut \\
\hline
\end{tabular}

Note: The Percentages of the tariff cuts applied to different products were designed in accord with the Indo-Lanka FTA details on tariff reductions. 
Table A.4. Macroeconomic and Trade Performance Results of Different Policy Scenarios

\begin{tabular}{|c|c|c|c|c|c|c|c|c|c|}
\hline Policy Scenarios & $\begin{array}{l}\text { Change } \\
\text { in } \\
\text { Value of } \\
\text { GDP (\%) }\end{array}$ & $\begin{array}{l}\text { Change in } \\
\text { Volume of } \\
\text { Exports } \\
\text { (US\$ Mil- } \\
\text { lion) }\end{array}$ & $\begin{array}{l}\text { Change in Vol- } \\
\text { ume of } \\
\text { Imports } \\
\text { (US\$ Million) }\end{array}$ & $\begin{array}{l}\text { Terms of } \\
\text { Trade } \\
\text { (\% change })\end{array}$ & $\begin{array}{c}\text { Trade } \\
\text { Balance } \\
\text { (US\$ } \\
\text { Million) }\end{array}$ & $\begin{array}{c}\text { Change in } \\
\text { Household } \\
\text { Utility } \\
\text { (\% change) }\end{array}$ & $\begin{array}{c}\text { Change in } \\
\text { Real } \\
\text { Returns to } \\
\text { Skilled } \\
\text { Labour (\% } \\
\text { change) }\end{array}$ & $\begin{array}{l}\text { Change in } \\
\text { Real Returns } \\
\text { to Unskilled } \\
\text { Labour (\% } \\
\text { change }\end{array}$ & $\begin{array}{c}\text { Change ir } \\
\text { Return on } \\
\text { Capital } \\
(\% \\
\text { change) }\end{array}$ \\
\hline \multicolumn{10}{|c|}{$\begin{array}{l}\text { 1. South Asian Free Trade Agreement } \\
\text { (SAFTA) }\end{array}$} \\
\hline India (IND) & 0.23 & 434.43 & 519.53 & 0.16 & -46.76 & 0.06 & 0.07 & 0.07 & 0.06 \\
\hline Sri Lanka (LKA) & 0.39 & 5.52 & 34.95 & 0.35 & -14.08 & 0.27 & 0.50 & 0.41 & 0.35 \\
\hline Bangladesh (BDG) & -0.15 & 264.23 & 238.70 & -0.41 & -34.51 & 0.05 & 0.35 & 0.38 & 0.31 \\
\hline Rest of South Asia (XSA) & 0.99 & 205.91 & 365.09 & 0.71 & -91.00 & 0.27 & 0.09 & 0.04 & 0.22 \\
\hline \multicolumn{10}{|l|}{ 2. South Asian Custom Union } \\
\hline India (IND) & -0.52 & 5285.98 & 5114.9 & -1.02 & -993.3 & 0.78 & 1.71 & 1.20 & 1.28 \\
\hline Sri Lanka (LKA) & 0.17 & -341.60 & -729.4 & 0.86 & 452.9 & 0.43 & -3.13 & -3.53 & -4.03 \\
\hline Bangladesh (BDG) & 1.26 & 718.47 & 613.2 & -1.01 & -42.4 & 1.01 & 0.87 & 0.71 & 0.68 \\
\hline Rest of South Asia (XSA) & 1.16 & -158.31 & 5.1 & 0.83 & -113.9 & 0.79 & 0.91 & 0.24 & 0.58 \\
\hline \multicolumn{10}{|c|}{$\begin{array}{l}\text { 3. Indo-Lanka Full Trade Liberalization Sce- } \\
\text { nario }\end{array}$} \\
\hline India (IND) & 0.06 & 60.9 & 83.5 & 0.04 & -5.5 & 0.01 & 0.00 & 0.01 & 0.05 \\
\hline Sri Lanka (LKA) & 0.15 & 19.7 & 46.6 & 0.17 & -26.8 & 0.17 & 0.64 & 0.55 & 0.45 \\
\hline Bangladesh (BDG) & 0.00 & -0.2 & -0.5 & 0.00 & 0.1 & 0.00 & 0.00 & 0.00 & 0.00 \\
\hline Rest of South Asia (XSA) & -0.02 & -1.5 & -2.7 & -0.01 & 0.1 & 0.00 & 0.01 & 0.00 & 0.00 \\
\hline India (IND) & -2.5 & 17975.0 & 18328.7 & -3.07 & -2979.6 & 1.24 & 3.67 & 3.45 & 2.94 \\
\hline Sri Lanka (LKA) & 5.6 & 1.3 & 573.8 & 4.25 & -334.2 & 2.71 & 4.30 & 4.46 & 3.69 \\
\hline Bangladesh (BDG) & -1.8 & 2624.1 & 2334.2 & -4.48 & -220.2 & 0.97 & 3.57 & 3.87 & 3.08 \\
\hline Rest of South Asia (XSA) & -1.5 & 2488.5 & 2841.1 & -1.06 & -667.6 & 0.94 & 3.54 & 3.31 & 2.70 \\
\hline
\end{tabular}


Table A.4. Macroeconomic and Trade Performance Results of Different Policy Scenarios (continued)

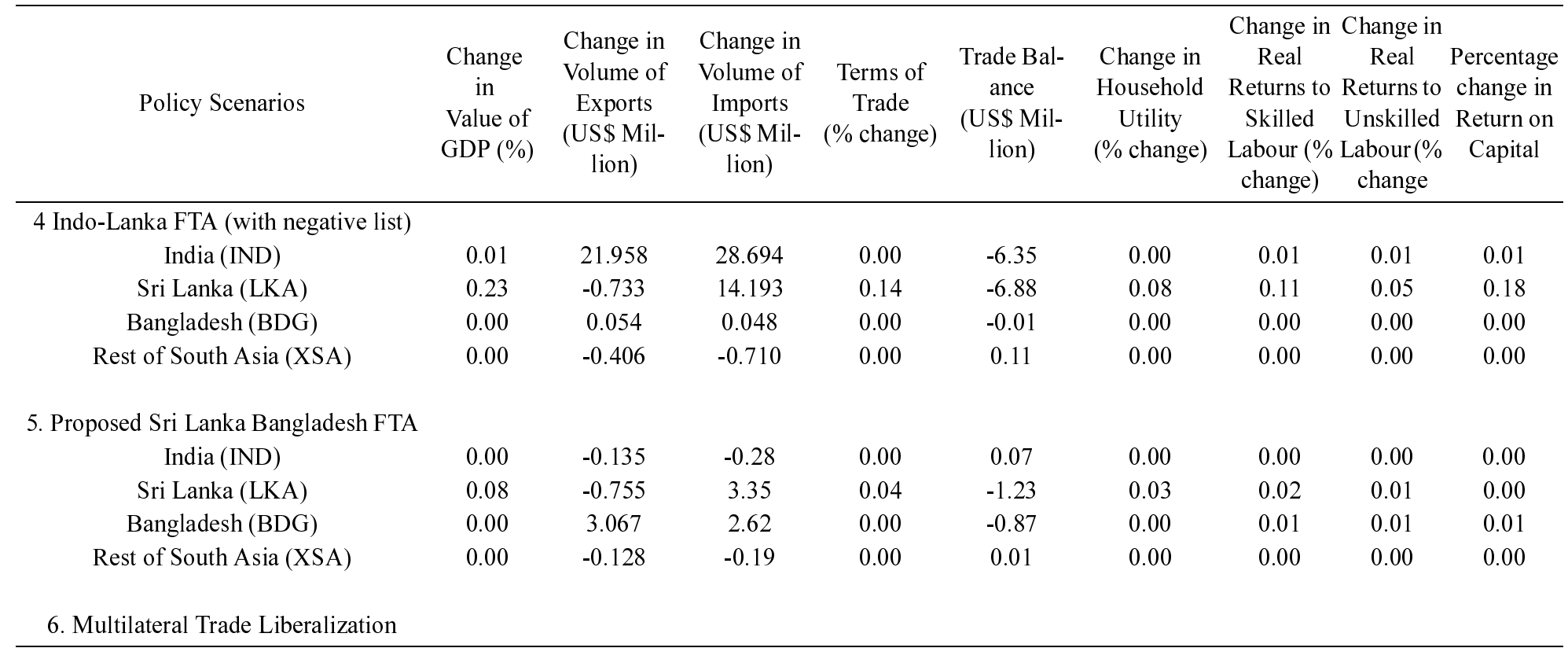

Source: Simulation results derived under different policy scenarios from GTAP version 6 (Database 2001) 
Table A.5. Percentage Change in Exports and Imports in Sri Lanka under different Policy Option

\begin{tabular}{|c|c|c|c|c|c|c|c|c|c|c|c|c|}
\hline \multirow[t]{2}{*}{ Industry } & \multicolumn{2}{|c|}{ SAFTA } & \multicolumn{2}{|c|}{$\begin{array}{c}\text { South Asian } \\
\text { Custom Union }\end{array}$} & \multicolumn{2}{|c|}{ ILFTA } & \multicolumn{2}{|c|}{$\begin{array}{c}\text { ILFTA } \\
\text { (with negative lists) }\end{array}$} & \multicolumn{2}{|c|}{$\begin{array}{c}\text { Sri Lanka-Bangladesh } \\
\text { FTA }\end{array}$} & \multicolumn{2}{|c|}{$\begin{array}{c}\text { Multilateral Trade } \\
\text { Liberalization }\end{array}$} \\
\hline & Exports & Imports & Exports & Imports & Exports & Imports & Exports & Imports & Exports & Imports & Exports & Imports \\
\hline$\overline{\text { PDR_PCR }}$ & 2.27 & 70.29 & 11.16 & 68.17 & 2.37 & 44.37 & 2.60 & -1.78 & -0.35 & -0.18 & 34.25 & 108.89 \\
\hline WHT_GRO & 7.11 & 0.26 & -26.4 & -1.09 & 0.07 & 0.16 & 0.42 & 0.04 & -0.12 & -0.13 & -7.07 & 1.74 \\
\hline V_F & 6.16 & 5.32 & 10.47 & 4.15 & 2.23 & 4.81 & 0.34 & 5.07 & -0.20 & -0.30 & -5.36 & 18.78 \\
\hline OSD_VOL & 40.16 & 4.2 & -7.14 & 4.17 & 2.41 & 2.19 & 3.09 & 2.03 & 21.56 & -0.92 & -37.62 & 10.75 \\
\hline PFB_OCR & 1.05 & 2.4 & 3.99 & -10.97 & 0.99 & 2.56 & 0.31 & 2.46 & -0.07 & -0.37 & 8.53 & -8.51 \\
\hline C_B_SGR & -25.84 & 1.69 & -26.93 & 2.01 & 5.22 & 2.25 & 5.83 & 2.09 & -0.18 & -0.21 & -24.05 & 6.32 \\
\hline RMK_MIL & 26.67 & 0.6 & 33.14 & -4.68 & -0.1 & 0.31 & 1.30 & -0.09 & -0.30 & -0.43 & 6.88 & 16.3 \\
\hline FSH & -0.56 & 2.16 & 0.58 & -5.98 & -0.37 & 0.99 & -0.04 & 0.47 & -0.07 & -0.07 & -2.74 & 16.2 \\
\hline CMT_OMT & 36.7 & 3.36 & 50.92 & 0.33 & 4.32 & 2.80 & 0.78 & 1.64 & -0.09 & -0.35 & -16.79 & 73.51 \\
\hline OFD & 0.96 & 2.67 & 8.65 & -5.84 & 0.42 & 2.88 & 0.30 & 2.43 & -0.14 & -0.15 & -16.39 & 22.39 \\
\hline B_T & 6.22 & 0.6 & 5.74 & 9.64 & -0.16 & 0.46 & 0.00 & 0.02 & -0.07 & -0.08 & 24.61 & 23.45 \\
\hline OFP & 20.3 & 0.7 & 26.59 & -1.07 & 11.62 & 0.59 & 0.18 & 0.31 & 9.84 & -0.33 & 9.51 & 8.92 \\
\hline TEX & 3.67 & -0.99 & -2.59 & -22.96 & -0.44 & -0.25 & 0.03 & -0.04 & 0.02 & -0.41 & 13.84 & 13.8 \\
\hline WAR & -1.71 & -1.91 & -18.97 & -20.74 & -0.62 & -0.74 & -0.11 & -0.16 & -0.17 & -0.47 & 16.17 & 10.94 \\
\hline LEA_LUM & -0.85 & -0.35 & 8.69 & -5.15 & -0.28 & 0.04 & -0.02 & 0.11 & -0.17 & -0.49 & 14.06 & 7.9 \\
\hline PPP & 23.1 & 1.95 & 14.99 & 2.9 & 26.64 & 2.08 & 9.75 & 0.71 & 1.43 & 0.04 & 17.32 & -0.34 \\
\hline CRP & 3.85 & 0.7 & -0.36 & -3.42 & 4.65 & 0.88 & -0.30 & 0.03 & 0.55 & -0.19 & -5.83 & 5.1 \\
\hline I_S_NFM_FMP & 57.9 & 1.89 & 28.76 & -4.01 & 62.13 & 2.64 & 21.98 & 1.23 & 4.67 & -0.04 & 18.3 & 4.04 \\
\hline ELE & -0.25 & 0.46 & -28.81 & -13.81 & 1.72 & 0.81 & 2.03 & 0.58 & -0.20 & -0.18 & 18.13 & 10.27 \\
\hline OME & 1.65 & 0.56 & -13.47 & -13.52 & 2.75 & 0.92 & 2.74 & 0.67 & 0.54 & -0.20 & 0.58 & 10.94 \\
\hline O_M & -1.68 & 0.46 & 12.55 & -10.8 & -1.44 & 0.60 & -0.48 & 0.32 & -0.31 & -0.36 & -39.39 & 8.12 \\
\hline $\mathrm{P}_{-} \mathrm{C}$ & 1.26 & -0.04 & -17.18 & -0.46 & 1.48 & 0.00 & -0.08 & 0.14 & -0.04 & -0.06 & -4.84 & 1.02 \\
\hline CIM & 4.95 & 0.83 & 4.72 & -12.74 & 1.43 & 1.05 & 1.57 & 0.74 & 4.56 & -0.15 & -11.96 & 10.87 \\
\hline T_S & -1.37 & 0.42 & 5.61 & -15.02 & -0.91 & 0.39 & -0.25 & 0.12 & -0.16 & -0.17 & -14.53 & 5.03 \\
\hline NTS & -1.47 & 0.88 & 4.37 & -28.12 & -1.01 & 0.72 & -0.32 & 0.19 & -0.19 & -0.12 & -19.41 & 12.72 \\
\hline OthPrimary & 10.18 & 0.6 & 82.69 & -0.11 & 10.72 & -0.18 & 10.90 & -0.03 & -0.07 & -0.08 & 39.61 & 3.29 \\
\hline NRE & 6.59 & 0.85 & 13.9 & -7.87 & 5.58 & 0.95 & -0.46 & 0.06 & 1.40 & -0.65 & 29.03 & 1.67 \\
\hline
\end{tabular}

Source: Simulation results derived under different policy scenarios from GTAP version 6 (Database 2001) 


\section{References}

Arvind Panagariya(2002), "South Asia: Does Preferential Trade Liberalization Make Sense?", Center for International Economics, Department of Economics, University of Maryland, College Park.

Bandara S. J ,Wusheng Yu(2001), "How Desirable is the South Asian Free Trade Area a Quantitative Assessment", SJFI-Working Paper no. 16.

Bhagwati J. (1993), "Regionalism and Multilaterism: an Overview", in J. De Melo and A. Panagariya (eds). "New Dimensions of Regional Integration", Cambridge University Press, Cambridge,U.K.

Dixon, P.B., Parmenter, B.R., Sutton, J. and Vincent, D.P. (1982), ORANI: Multi sectoral Model of the Australian Economy, Amsterdam, North-Holland.

Hertal, T. W (ed) (1997), Global Trade Analysis: Modeling and Applications, New York: Cambridge University Press.

M. Asaduazzaman, Nazeen Ahmed, Sharif M. Hossain and Subrata Sarker(2003), "South Asian Free Trade Area: an Analysis for Policy Options for Bangladesh", WTO Project Working Paper, Bangladesh and the WTO project.

McDougall, R.A., Elbehri, A. Truong, T.P. (1998), "Global Trade, Assistance, and Protection", Centre for Global Trade Analysis, Purdue University.

Pravin Krishna(2003), “Are Regional Trading Partners "Natural"?", Journal of Political Economy $y_{2}$ University of Chicago, 111, 1 : 202-225.

Pigato, M, Farah, C., Itakura, Jun. K, Martin. W, Murrell. K, and T. G Srinivasan(1997), South Asia's Integration into the World Economy, Washington, D.C: World Bank.

Rajapakse, P and Arunatilleke, N. (1997), "World Reduction in Trade Barriers Promote IntraSAARC Trade? a Sri Lankan Perspective”, Journal of Asian Economies, 8(1), pp. 95-115.

Siriwardena, M.(2001), "Looking Beyond SAARC: Some Trade Policy Options for Sri Lanka", Asian Studies Review, 25(4), pp. 453-478.

Siriwardena, M.(2003), "Trade Liberalization in South Asia: Free Trade Area or Custom Union”, South Asia: Journal of South Asian Studies, 26(3), pp.309-329.

Siriwardena, M.(2004), "An Analysis of the Impact of Indo-Lanka Free Trade Agreement and Its Implications for Free Trade in South Asia", Journal of Economic Integration, 19(3), pp. 568-589.

Siriwardena, M. and Yang. J. (2007), "Effects of Proposed Free Trade Agreement between India and Bangladesh", South Asian Economic Journal, 8(1), pp. 21-38.

Samaratunga, R. H. S. (1999), "Essays in Trade Policy and Economic Integration with Special Reference to South Asia", La Trobe University, Melbourne.

Saman Kelegama(2001), "Impediments to Regional Economic Cooperation in South Asia", Institute of Policy Studies of Sri Lanka.

Sonu Jain, Rajiv Kumar, N. Srinivasan(2004), South Asia Regional Integration, India Country Note, South Asian Regional Economic Coorperation: a Private Sector Perspectives, The World Bank/International Monetary Fund, Washington D.C. 